\title{
Are we Adequately Preparing Teachers to Partner with Families?
}

\author{
Tamara Sewell
}

Published online: 1 February 2012

(C) Springer Science+Business Media, LLC 2012

\begin{abstract}
Family-centered practice is accepted as best and effective practice by early childhood professional organizations including the National Association for the Education of Young Children, The Council for Exceptional Children's Division of Early Childhood, and The National Board of Professional Teaching Standards. The main objective of family-centered practice is the development of a reciprocal family partnership in order to provide effective early childhood services to young children and families. The literature reveals that there are issues in early childhood teacher preparation in terms of the level of emphasis on family-centered practice, the implementation of a standalone course versus infusion of family-centered content throughout coursework, and the linkage of coursework to practical experience. Teacher perceptions of families have a great deal of influence on the nature of relationships between teachers and families. This literature review illuminates the necessity for teacher preparation programs and school administration to regularly review programming to make certain that students and practicing teachers are adequately prepared to efficiently serve young children in the context of their families.
\end{abstract}

Keywords Early Childhood - Teacher Preparation . Personnel Preparation · Family

T. Sewell $(\bowtie)$

Bank Street College, 610 West 112th Street,

New York, NY 10025, USA

e-mail: tsewell@bankstreet.edu

\section{Introduction}

Young children are the center of their family and as such their families are a wellspring of knowledge when it comes to their child's development and learning. Early childhood teachers have regular opportunities to interact with families and gather knowledge to influence their teaching practices. However, challenges arise when a teacher has not been prepared to partner effectively with families and to best serve children within the context of the family.

According to the Council for Exceptional Children's Division for Early Childhood (DEC), "practitioners in early education and intervention must be prepared to work with families whose cultural, ethnic, linguistic, and social backgrounds differ from their own" (Stayton et al. 2003, p. 11). "Class lectures, simulations, and supervised home visits with families, as well as interviews and informal conversations" (Hyson 2003, p. 140) are integral to the pre-service teachers' learning process.

The DEC's preparation program standards for early childhood professionals were developed in conjunction with the National Association for the Education of Young Children (NAEYC) and the National Board for Professional Teaching Standards (NBPTS). The DEC's program standards emphasize that the professional become involved as equal partners with families early on and that a reciprocal relationship should be maintained throughout the partnership. Additionally, because families vary in terms of priorities, resources, concerns, cultural background, views of education, and how they support their children's development and learning, training should involve families that are diverse in nature (Stayton et al. 2003). Providing comprehensive training to professionals has the potential to increase the implementation and effectiveness of familycentered practices. 
Research concerning teacher preparation in the field of early childhood is limited, particularly in the area of family-centered practices. Several surveys have focused on this increasingly important topic, but results are, at best, inconsistent. However, there two distinct issues that are repeated throughout the literature: teacher perceptions of families and the focus on family partnership in teacher preparation programs.

\section{What are Teachers' Perceptions of Family-Centered Practice?}

Teachers and administrators struggle to partner with families due to the lack of preparation. In 2006, MetLife surveyed 1,001 public school teachers and found that "teachers consider engaging and working with parents as their greatest challenge and the area they were least prepared to manage during their first year" (Harvard Family Research Project 2006, p. 1). More specifically $31 \%$ of the teachers reported that the greatest challenge was in encouraging involvement and communicating with the family (Markow et al. 2006). The dearth of training opportunities has resulted in teachers feeling ill-prepared to work with families, which creates a multitude of challenges for the teacher, child, and family.

In-service training opportunities and topics impact practitioner perceptions and practices. Bruder et al. (2009) completed electronic surveys and phone interviews with 51 Part C coordinators and 49 coordinators of 619 programs regarding the implementation of professional development that is both systematic and sustainable. Thirty-nine of the Part C states and 35 of the 619 respondents reported offering in-service training systems that were systematic and sustainable. The training content for both Part $\mathrm{C}$ and 619 was based on administrative or consultant recommendations. Only 11 of the 51 Part $\mathrm{C}$ coordinators reported training content regarding partnering with families and none of the 619 respondents reported inclusion of family content.

Rothenberg and McDermot of the Sage College School of Education expanded on the MetLife survey by creating focus groups to gain a qualitative understanding of the nature of family-centeredness and its implementation. Teachers who were involved in the groups reported that they actually avoided working with families and found such work to be unappealing. Parents involved in the focus groups reported that they only felt comfortable working with those teachers that treated children and families with respect and high regard (Harvard Family Research Project 2006). Based on these views, it is easy to see that an unproductive cycle of teachers and families avoiding interaction is easily formed and maintained.

\section{How are we Preparing Teachers to Work with Families?}

The Center to Inform Personnel Preparation, Policy and Practice in Early Intervention and Early Childhood Special Education (n.d.) conducted a survey of 5,659 institutions offering degree programs for all services under IDEA. Of the 1,131 respondents, $86.43 \%$ reported that they offer at least one course related to families, specifically with a focus on families with children ages three to five. Another survey, by The National Prekindergarten Center in 2004, reported a more conservative percentage of only $61 \%$ who reported that they offered at least one course dedicated to preparing professionals to work with families (Maxwell et al. 2006).

In order to establish the amount of family-centered content taught in early childhood teacher preparation programs, Rupiper and Marvin (2004) surveyed 82 institutions across the United States. Results demonstrated that familycentered content was infused across course curriculum. Twenty-eight institutions indicated that family-centered content was taught in an independent undergraduate course. Course credit hours ranged from 2 to $8 \mathrm{~h}$ with most respondents indicating three credit hours. Primary content of the family-centered coursework included knowledge of families, IFSP skills, respecting diversity, communication skills, and knowledge of teamwork.

Chang et al. (2005) reported on a national survey of early childhood teacher preparation programs completed in 1999 by the National Center for Early Development and Learning. One of the purposes of the study was to quantify the amount and type of coursework and practicum experiences related to families, collaboration, and home visiting required by early childhood preparation programs (Chang et al. 2005). The sample included 438 associate and bachelor level programs in 47 states that prepare individuals to work with children ranging in age from birth to four years. Participants were asked to complete a survey that included questions about required coursework and practical experiences related to families. Just under $60 \%$ of both associates and bachelor's degree programs offered at least one families course. Data also showed that students often had practical experiences with families, including home visits, without having had any in-class preparation prior to or in conjunction with the experience.

The Centre for Community Child Health in Australia (2003) convened focus groups based on common issues found in the literature on the subject of early childhood teacher preparation. One of the major issues identified by the focus groups was that students were unprepared for work with young and developing families. In particular, members of the focus group believed that although family-centered philosophies, beliefs, and practices are incorporated into 
course content, opportunities for students to apply and demonstrate comprehension are limited (Centre for Community Child Health 2003).

In an effort to establish how family-centered practice was taught to future teachers, Sewell (2007) conducted a critical study surveying 21 undergraduate early intervention/early childhood special education teacher preparation programs. Participants were asked to specify how familycentered practices were taught as well as how students were afforded the opportunity to articulate and apply those practices. Approximately $38 \%$ of the respondents indicated that family-centered practice was taught in an independent course. Ninety percent of the respondents indicated that more than $50 \%$ of family-centered focus was infused across course content. Eighty-one percent of respondents indicated that family-centered methods courses were linked to field experiences, however, direct contact with families during these experiences was often limited due to the nature of the placements. Echoing The Centre for Community Child Health in Australia's (2003) and Chang et al. (2005) results, participants indicated that students were taught family-centered practices and had moderate opportunities to articulate them but very little opportunity to actually apply the practices with families.

To gain a comprehensive understanding of early childhood teacher preparation program's strengths and weaknesses, Bruder and Dunst (2005) surveyed programs to determine where training emphasis was placed in regards to the following factors: family-centered practice, crossdisciplinary models, service coordination, development of IFSPs, and natural environments. Eight disciplines serving children under IDEA were examined, and a total of 449 programs completed a 30 -item survey. Results indicated family-centered intervention was the only practice that constituted primary emphasis across all eight disciplines; however, none of the disciplines felt as though they were adequately prepared to work with families. The researchers recommend embedding family-centered practices into teacher preparation programs in order to prepare students to work effectively with children and families (Bruder and Dunst 2005).

\section{Are we Influencing Preservice Teachers' Perceptions?}

Teacher's perceptions of families impact their interactions with families. Murray and Mandell (2004) evaluated two pre-service programs designed to prepare graduates to provide family-centered services using the Family-Centered Pre-service Model (FCPM). The FCPM program was based on the teacher preparation professional standards developed by both NAEYC and DEC. The researchers interviewed 22 students to examine attitudes and beliefs, as well as aptitude, about issues relating to diversity. Students were also asked to report on family-centered practices that they had the opportunity to apply (Murray and Mandell 2004).

Prior to the program, approximately $70 \%$ of the participants had little experience with families and a limited understanding of family-centered practices. The FCPM program was effective in changing the students' attitudes and beliefs about working with diverse families and increasing the students understanding of families in general. In addition, didactic teaching in conjunction with experiential practice resulted in increased participant confidence to effectively utilize and apply practices (Murray and Mandell 2004).

Additional research exploring pre-service teachers' perceptions and experiences of preparedness training was conducted by Blasi (2002). Twenty-six students enrolled in a course titled "Principles of Interprofessional Collaboration," completed pre- and post-test questionnaires. At the time of the pre-test, $38 \%$ of the students felt prepared to work with children and families. Upon completion of the course, $58 \%$ of the students felt prepared. This increase is due to the fact that students "realized the importance of valuing and respecting parents as their children's first and most important teachers, and...saw their role in working with families as more of a 'shared power' within a 'familyfirst' perspective” (Blasi 2002, p. 115). The limited positive results of the course further illuminate the need to expand and increase the emphasis on family-centered learning opportunities beyond a single course.

Giallourakis et al. (2005) developed a measure to explore the specific beliefs, skills, and practices of graduate students in the field of early childhood education. The survey results indicated that a moderate level of family involvement is included in programs, but has little impact on how students perceive their education. As would be expected, frequency of contact was correlated with beliefs and practices on family-centered approaches. The two themes that evolved from the survey responses were increased empathy and awareness as well as the application of new skills in relation to family-centered practice. One student shared that the experience greatly impacted his/her perspective and work in helping him/her realize "that even the least participatory parent still holds immense knowledge regarding their child and family, and the needs and resources of the family" (Giallourakis et al. 2005, p. 4).

Students' expressive writing also gives insight into their perceptions of family-centered practice. Pang and Wert (2010) conducted a study of 87 undergraduate students enrolled in an introduction to early intervention course that introduced students to family-centered philosophy and practices. The students completed pre and post essays about their beliefs vis-à-vis the involvement of families in 
early intervention service delivery and how they would involve families in their practice as early interventionists. The researchers found that at both the pre and post points of the study, students recognized the importance of family involvement; however, in their post essays students placed more emphasis on actual practices, involvement of the family as a whole unit, the roles that families and professionals play, the importance of involving pre-service teachers with families early, and the challenges related to implementing family-centered practices (Pang and Wert 2010). Pre-service students involved in the study recognized family support as a critical component of early intervention services and noted that family partnerships facilitated carryover of functional skills into multiple settings. This carryover reduced the pressure on the teacher to provide the primary support, increased both family and teacher understanding of the child's development and progress, and improved functionality of team goals.

Bingham and Abernathy (2007) used concept mapping to illuminate 49 pre-service students' changing attitudes and perceptions throughout a 16 week course on the topic of partnering with families. The students completed a pre- and post-course concept map depicting their perceptions about serving individuals with disabilities and their families. Differences between pre- and post-course perceptions included the expansion of the idea of communication from "getting the job done" to "advocating for children and families" and "a more reciprocal interaction with families" with students "relinquishing the role of power broker and embracing the role of advocate" (Bingham and Abernathy 2007, p. 52). Students saw the teacher's role as more collaborative not only with families, but also the community at large. However, not all results were as encouraging. In the pre-course maps, $73 \%$ of the students positioned the teacher as the expert. The post-course maps showed only a $8 \%$ change in this perception of roles. "Regardless of the numerous activities in which they participated and the family stories they heard, they did not move away from seeing the focus of the class on the special education system and its requirements" (Bingham and Abernathy 2007, p. 55). Bingham and Abernathy hypothesize that perhaps the strong focus on the administrative aspect of working with children with special needs (the Individuals with Disabilities Education Act requirements, documentation, education plans, etc.) overwhelm the students and therefore overshadow the importance of reciprocal family partnerships.

Results from the focus groups based on the MetLife survey spurred Rothenberg and McDermot to begin implementing new strategies in coursework. Practicum students were required to hold routine conferences with parents from a strengths-based perspective. These conferences were meant to focus on positive news about children, while also allowing parents to voice the views, goals, and dreams that they have for their children. Requiring family visits provided the students with insight into the child's world within the context of the family. Seasoned supervising teachers felt that the students' work with the families would create problems, but the families were quite receptive to the extra involvement and the students reported enjoying the contact with families and found that working with families resulted in positive outcomes for the children (Harvard Family Research Project 2006).

\section{Conclusion}

Partnering with families is best and effective practice and can only enhance children's development and learning. Nevertheless, many teachers find the idea of partnering with families a daunting and unmanageable task due to lack of preparation and training. All too often preparation does not emphasize the importance of partnering with families enough to enable pre-service teachers to practically apply the knowledge.

Increased and focused student contact with families throughout their teacher training is clearly necessary. Involvement of families in the development of coursework and in-service trainings as well as the delivery of course content and fieldwork opportunities is a key to improving student comprehension of the importance of family partnership. This concept ensures that course content is realistic and offers real-life examples. Families can act as co-instructors or guest speakers and share their experiences and lives through practical field experiences.

The research demonstrates that even one course can impact pre-service teachers' perceptions regarding partnerships with families. But, one course is not sufficient to adequately prepare teachers to work reciprocally with families. Theoretically, infusing family-centeredness throughout early childhood course work is the best option. However, programs must consider that "content taught, including both emphasis and pedagogical style, varies according to each individual instructor's knowledge and experience" (Sewell 2007, p. 61). Infusion of content across coursework is ideal as long as the emphasis of content is regulated and aligned with course objectives and practical experience so that regardless of instructor, students receive consistent information. In addition, ongoing in-service training is imperative in order to not only educate practicing teachers, but to support them in their daily practice with families.

It is vital for both early childhood teacher preparation programs and in-service trainers to ensure pre-service students and practicing teachers are adequately prepared to partner with families in order to best serve the needs of the child and family. 


\section{References}

Bingham, A., \& Abernathy, T. V. (2007). Promoting family-centered teaching: Can one course make a difference? Issues in Teacher Education, 16(1), 37-60.

Blasi, M. W. (2002). An asset model: Preparing pre-service teachers to work with children and families "of promise". Journal of Research in Childhood Education, 17(1), 106-121.

Bruder, M. B., \& Dunst, C. J. (2005). Personnel preparation in recommended early intervention practices: Degree of emphasis across disciplines. Topics in Early Childhood Special Education, 25(1), 25-33.

Bruder, M. B., Morgro-Wilson, C., Stayton, V. D., \& Dietrich, S. L. (2009). The national status of in-service professional development systems for early intervention and early childhood special education practitioners. Infants and Young Children, 22(1), 13-20.

Centre for Community Child Health. (2003). Final report on research to inform the development of a capacity building program. Canberra, ACT: Australian Council for Children and Parenting, Commonwealth Department of Family and Community Services.

Chang, F., Early, D. M., \& Winton, P. J. (2005). Early childhood teacher preparation in special education at 2- and 4-year institutions of higher education. Journal of Early Intervention, $27(2), 110-124$.

Giallourakis, A., Pretti-Frontczak, K., \& Cook, B. (2005). Understanding family involvement in the preparation of graduate students: Measuring family-centered beliefs, skills, systems, and practices. Cambridge, MA: Harvard Family Research Project.

Harvard Family Research Project. (2006). Is teacher preparation key to improving teacher practices with families? What are the alternatives? FINE Network. Retrieved from http://www.gse. harvard.edu/hfrp/projects/fine/memberinsights.html.
Hyson, M. (Ed.). (2003). Preparing early childhood professionals: NAEYC's standards for programs. Washington, DC: National Association for the Education of Young Children.

Markow, D., Moessner, C., \& Horowitz, H. (Eds.). (2006). The MetLife survey of the American teacher: Expectations and Experiences. New York: Metropolitan Life Insurance Company.

Maxwell, K. L., Lim, C.-I., \& Early, D. M. (2006). Early childhood teacher preparation programs in the United States: National report. Chapel Hill, NC: The University of North Carolina, FPG Child Development Institute.

Murray, M. M., \& Mandell, C. J. (2004). Evaluation of a familycentered early childhood special education pre-service model by program graduates. Topics in Early Childhood Special Education, 24(4), 238-249.

Pang, Y., \& Wert, B. (2010). Preservice teachers' attitudes towards family-centered practices in early intervention: An implication for teacher education. Educational Research, 1(8), 253-262.

Rupiper, M., \& Marvin, C. (2004). Preparing teachers for familycentered services: A survey of pre-service curriculum content. Teacher Education and Special Education, 27(4), 384-395.

Sewell, T. (2007). Family-centered practice in early intervention and early childhood special education personnel preparation. (Doctoral dissertation). Retrieved from Proquest. (Publication number AAT 3273938).

Stayton, V. D., Miller, P. S., \& Dinnebeil, L. A. (Eds.). (2003). DEC Personnel preparation in early childhood special education: Implementing the DEC recommended practices. Longmont, CO: Sopris West.

The Center to Inform Personnel Preparation, Policy and Practice in Early Intervention and Early Childhood Special Education. (n.d.). Part $C$ data report. Retrieved from http://www.uconnuc edd.org/publications/files/PPDataPartCweb.pdf. 